\title{
PERBEDAAN PENGGUNAAN METODE CERAMAH DENGAN METODE CERAMAH KOMBINASI MEDIA VIDEO TERHADAP PENGETAHUAN DAN TINDAKAN CUCI TANGAN PAKAI SABUN SISWA
}

\author{
Studi dilakukan di Sekolah Dasar Negeri 1 Dawan Klod Kecamatan Dawan \\ Kabupaten Klungkung Tahun 2018
}

Ni Kadek Rastini ${ }^{1}$, Ni Made Marwati ${ }^{2}$

\begin{abstract}
Handwashing with soap is able to reduce diarrhea by as much as $45 \%$, but the use of soap for hand washing only reaches about 3\% of the entire community. Counseling is very important to increase the knowledge, attitude and practice of students in maintaining their own health. The purpose of this research is to know the difference of using lecture method with lecture method combination of video media to knowledge and action of handwashing with soap at Public Elementary School 1 Dawan Klod. The type of research used is Pre Experimental research type with The One-Group Pretest-Posttest Design. The population in this research is all the students of class II and III in Public Elementary School 1 Dawan Klod with the sample of research as many as 44 respondents. Data analysis using Mann Whitney test. The result of the research shows that there is no difference in the use of lecture method with video lecture method on knowledge and action handwashing with soap students ( $p$ value of knowledge $=0,283$ and action $=$ 0,361). Suggestions that can be given to Puskesmas can use lecture and video methods to improve the achievement of health promotion goals to school children about hand washing.
\end{abstract}

Keywords: Lecture; Video; Knowledge; Action

Indonesia saat ini sedang gencar dalam menggalakkan Pembangunan Kesehatan pada periode 2015-2019 melalui Program Indonesia Sehat dengan 3 pilar salah satunya paradigma sehat yang dilakukan dengan strategi pengarusutamaan kesehatan dalam pembangunan kesehatan, penguatan promotif, preventif, dan pemberdayaan masyarakat. Selain itu pula adanya program lain seperti Germas. Salah satu kegiatan utama yang dilakukan dalam rangka germas yaitu peningkatan Perilaku Hidup Bersih dan Sehat (PHBS) (1).
PHBS merupakan bagian dari upaya peningkatan promotif kesehatan dan pencegahan (preventif) penyakit (2). Pelaksanaan program Perilaku Hidup Bersih dan Sehat dikelompokkan menjadi 5 tatanan yaitu PHBS di Sekolah, PHBS di Rumah Tangga, PHBS di Institusi Kesehatan, PHBS di Tempat-tempat umum dan PHBS di Tempat Kerja. Dari kelima tatanan tersebut tatanan sekolah merupakan tatanan awal untuk membentuk sumber daya yang sehat dan berkualitas (3).

Tatanan sekolah merupakan salah satu ruang lingkup promosi kesehatan. Promosi kesehatan di lingkungan

1 Mahasiswa Jurusan Kesehatan Lingkungan Poltekkes Denpasar

2 Dosen Jurusan Kesehatan Lingkungan Poltekkes Denpasar 
sekolah sangat efektif karena anak sekolah merupakan sasaran yang mudah dijangkau karena sudah terorganisasi dengan baik. Selain itu pula anak sekolah berada dalam tahap pertumbuhan dan perkembangan sehingga mudah untuk dibimbing, diarahkan, dan ditanamkan kebiasaankebiasaan baik (4)

Salah satu indikator PHBS pada tatanan sekolah yaitu mencuci tangan dengan air yang mengalir dan menggunakan sabun yang lebih dikenal dengan Cuci Tangan Pakai Sabun (CTPS). Cuci tangan pakai sabun mampu untuk mengurangi angka diare sebanyak $45 \%$, tetapi pemakaian sabun untuk cuci tangan hanya mencapai sekitar 3\% dari seluruh masyarakat yang menggunakan sabun untuk cuci tangan (5).

Maka dari itu perlu adanya pendidikan kesehatan berupa penyuluhan. Menurut Notoatmodjo (3), penyuluhan merupakan bagian dari pendidikan kesehatan yang bertujuan untuk meningkatkan pengetahuan, sikap, dan praktik masyarakat dalam memelihara dan meningkatkan kesehatan mereka sendiri. Penyuluhan dapat dilaksanakan antara lain dengan metode ceramah. Dalam penelitian ini penggunaan metode ceramah didasari dengan metode yang sering dipakai untuk penyuluhan di Puskesmas. Di samping itu pula untuk menyampaikan informasi kesehatan terhadap individu maupun kelompok perlu adanya suatu media promosi kesehatan Media yang akan digunakan yaitu media elektronik berupa video.

Menurut penelitian yang dilakukan Andrianus (6), media promosi kesehatan menggunakan video dan modul secara signifikan memberikan pengaruh praktik cuci tangan. Hasil penelitian membuktikan jika hasil promosi kesehatan menggunakan media video lebih efektif dibandingkan dengan media modul dilihat dari mean reank antara kedua kelompok, yaitu 14,70 pada modul dan 10,50 pada video.

Berdasarkan studi pendahuluan yang dilakukan peneliti di SD Negeri 1 Dawan Kelod diperoleh dari 7 orang yang diwawancara sebanyak 5 orang tidak tahu tentang CTPS sedangkan 2 orang mengatakan tahu tentang CTPS. Disamping itu pula siswa tidak mendapatkan penyuluhan tentang CTPS secara rutin dari pihak Puskesmas. Kebiasaan cuci tangan siswa sekolah dasar tersebut juga belum sesuai dengan cara mencuci tangan yang baik seperti hanya menggunakan air bersih saja tanpa menggunakan sabun untuk mencuci tangan.

Mengingat pentingnya promosi kesehatan untuk meningkatkan pengetahuan serta tindakan siswa dengan penggunaan metode dan media yang efektif maka peneliti tertarik melakukan penelitian mengenai perbedaan penggunaan metode ceramah dengan metode ceramah kombinasi media video terhadap pengetahuan dan tindakan Cuci Tangan Pakai Sabun di SD Negeri 1 Dawan Klod Tahun 2018. Adapun tujuan khusus dari penelitian ini antara lain (a) untuk mengetahui pengetahuan CTPS sebelum dan setelah diberi penyuluhan dengan metode ceramah, (b) untuk mengetahui pengetahuan CTPS sebelum dan setelah diberi penyuluhan dengan metode ceramah kombinasi media video, (c) untuk mengetahui tindakan CTPS sebelum dan setelah diberi penyuluhan dengan metode ceramah, (d) untuk mengetahui tindakan CTPS sebelum dan setelah diberi penyuluhan dengan 
metode ceramah kombinasi media video, (e) untuk menganalisis perbedaan penggunaan metode ceramah dengan metode ceramah kombinasi media video terhadap pengetahuan CTPS, (f) untuk menganalisis perbedaan penggunaan metode ceramah dengan metode ceramah kombinasi media video terhadap tindakan CTPS.

\section{Metode}

Jenis penelitian yang digunakan adalah jenis penelitian Pre Eksperimental. Penelitian jenis ini hasilnya merupakan variabel dependen bukan semata-mata dipengaruhi oleh variabel independen. Rancangan penelitian yang dipergunakan adalah The One-Group Pretest-Posttest Design. Dalam rancangan ini, peneliti memberikan perlakuan pada kelompok studi tetapi sebelumnya diukur atau dites dahulu (pretest) selanjutnya setelah perlakuan kelompok studi diukur atau ditest kembali (posttest). Dalam penelitian ini dilakukan pada dua kelompok yaitu

\section{Hasil Penelitian}

1. Karakteristik responden

a. Kelas responden

Dalam penelitian ini jumlah siswa dalam kelas pada kelompok ceramah antara kelas II dan III adalah sama dengan jumlah 11 orang (50\%). Pada kelompok ceramah + video, jumlah siswa paling banyak berada di kelas II dengan jumlah 12 orang $(54,5 \%)$ sedangkan kelas III dengan jumlah 10 orang $(45,5 \%)$.

b. Umur responden

Umur responden pada kelompok ceramah paling banyak adalah pada umur 8 tahun sebanyak 10 orang $(45,5 \%)$ dan yang paling sedikit pada umur 6 tahun sebanyak 1 orang $(4,5 \%)$. Pada kelompok ceramah + video, umur responden paling banyak kelompok ceramah dan kelompok ceramah kombinasi video.

Tempat penelitian berlokasi di SD Negeri 1 Dawan Klod. Waktu penelitian dilakukan pada bulan Januari - Juli 2018. Populasi dalam penelitian ini adalah siswa kelas II dan III di SD Negeri 1 Dawan Klod yang berjumlah 56 orang, kelas II sebanyak 27 orang dan kelas III sebanyak 29 orang. Sampel penelitian yang digunakan sebanyak 44 orang di mana siswa yang dijadikan sampel dengan kriteria inklusi yaitu siswa kelas II dan III yang aktif bersekolah di SD Negeri 1 Dawan Klod dan hadir saat dilakukan penyuluhan sedangkan untuk kriteria eksklusi sampel yaitu siswa yang tidak bisa hadir saat penyuluhan dengan alasan sakit maupun izin. Dalam penelitian ini akan dibagi sampel penelitian menjadi dua kelompok yaitu kelompok ceramah dan kelompok ceramah kombinasi video. Penentuan kedua kelompok tersebut akan dilakukan dengan cara Simple Random Sampling.

pada umur 8 tahun sebanyak 12 orang $(54,5 \%)$ dan paling sedikit berada pada umur 10 tahun sebanyak 2 orang $(9,1 \%)$.

c. Jenis kelamin responden

Jenis kelamin responden pada kelompok ceramah paling banyak adalah laki-laki sebanyak 14 orang $(63,6 \%)$ dan yang paling sedikit pada perempuan sebanyak 8 orang $(36,4 \%)$. Pada kelompok ceramah + video, jenis kelamin responden paling banyak adalah laki-laki sebanyak 12 orang $(54,5 \%)$ dan untuk jenis kelamin perempuan sebanyak 10 orang $(45,5 \%)$. 
2. Pengetahuan CTPS sebelum dan setelah diberikan penyuluhan menggunakan metode ceramah dengan metode ceramah kombinasi video

Tabel 1

Perbedaan Rata-Rata Pretest dan Posttest Pengetahuan Siswa Tentang CTPS di SD Negeri 1 Dawan Klod Tahun 2018

\begin{tabular}{lcccc}
\hline \multicolumn{1}{c}{ Kelompok } & Mean Pretest & Mean Posttest & Selisih & $p$ value \\
\hline $\begin{array}{l}\text { Ceramah } \\
\text { Ceramah }\end{array}$ & 10,18 & 10,91 & 0,73 & 0,078 \\
$\begin{array}{l}\text { Kombinasi } \\
\text { Video }\end{array}$ & 11,23 & 11,45 & 0,22 & 0,320 \\
\hline
\end{tabular}

Setelah dilakukan analisis menggunakan uji Wilcoxon diperoleh nilai rata-rata pengetahuan sebelum diberikan penyuluhan dengan metode ceramah sebesar 10,18 sedangkan setelah dilakukan penyuluhan sebesar 10,91 dengan selisih nilai 0,73 . $P$ value yang diperoleh sebesar 0,078 .
Setelah dilakukan analisis menggunakan uji Wilcoxon diperoleh nilai rata-rata pengetahuan sebelum dilakukan penyuluhan dengan metode ceramah video sebesar 11,23 dan setelah dilakukan penyuluhan dengan metode ceramah video sebesar 11,45 dengan selisih nilai sebesar 0,22 . $P$ value yang diperoleh sebesar 0,320 .

3. Tindakan CTPS sebelum dan setelah diberi penyuluhan menggunakan metode ceramah dengan metode ceramah kombinasi media video

Tabel 2

Perbedaan Rata-Rata Pretest dan Posttest Tindakan Siswa Tentang CTPS di SD Negeri 1 Dawan Klod Tahun 2018

\begin{tabular}{lcccc}
\hline \multicolumn{1}{c}{ Kelompok } & Mean Pretest & Mean Posttest & Selisih & $p$ value \\
\hline Ceramah & 4,45 & 11,91 & 7,46 & 0,000 \\
$\begin{array}{l}\text { Ceramah } \\
\text { Kombinasi Video }\end{array}$ & 4,36 & 11,45 & 7,09 & 0,000 \\
\hline
\end{tabular}

Setelah dilakukan analisis menggunakan uji Wilcoxon diperoleh nilai rata-rata tindakan CTPS sebelum dilakukan penyuluhan dengan metode ceramah sebesar 4,45 dan setelah dilakukan penyuluhan dengan metode ceramah sebesar 11,91 dengan selisih nilai sebesar 7,46. $P$ value yang diperoleh sebesar 0,000 .
Setelah dilakukan analisis menggunakan uji Wilcoxon diperoleh nilai rata-rata tindakan CTPS sebelum dilakukan penyuluhan dengan metode ceramah kombinasi media video sebesar 4,36 dan setelah dilakukan penyuluhan dengan metode ceramah kombinasi media video sebesar 11,45 dengan selisih nilai sebesar 7,09. $P$ value yang diperoleh sebesar 0,000 . 
4. Perbedaan penggunaan metode ceramah dengan metode ceramah kombinasi media video terhadap pengetahuan CTPS

Tabel 3

Hasil Uji Mann Whitney Pengetahuan Siswa Tentang CTPS pada Kelompok Ceramah dengan Kelompok Ceramah Kombinasi Video Tahun 2018

\begin{tabular}{ccccc}
\hline No & Kelompok & Mean Posttest & p value & Kemaknaan \\
\hline 1 & Ceramah & 10,91 & \multirow{2}{*}{0,283} & Tidak Signifikan \\
2 & Ceramah + Video & 11,45 & & \\
\hline
\end{tabular}

Setelah dilakukan uji Mann perbedaan secara signifikan Whitney diperoleh $p$ value sebesar pengetahuan siswa antara kelompok 0,283 . Ini menunjukan $p$ value $>0,05$ ceramah dengan kelompok ceramah berarti H0 diterima atau tidak ada kombinasi video.

5. Perbedaan penggunaan metode ceramah dengan metode ceramah kombinasi media video terhadap tindakan CTPS

Tabel 4

Hasil Uji Mann Whitney Tindakan Siswa Tentang CTPS pada Kelompok Ceramah dengan Kelompok Ceramah Kombinasi Video Tahun 2018

\begin{tabular}{lllll}
\hline No. & Kelompok & $\begin{array}{c}\text { Mean } \\
\text { Posttest }\end{array}$ & p value & Kemaknaan \\
\hline 1 & Ceramah & 11,91 & 0,361 & Tidak Signifikan \\
2 & Ceramah + Video & 11,45 & & \\
\hline
\end{tabular}

Setelah dilakukan uji uji Mann Whitney diperoleh $p$ value sebesar 0,361 . Ini menunjukan $p$ value $>0,05$ berarti H0 diterima atau tidak ada perbedaan secara signifikan tindakan siswa antara kelompok ceramah dengan kelompok ceramah kombinasi media video.

\section{Pembahasan}

\section{Pengetahuan CTPS sebelum dan setelah diberi penyuluhan dengan metode ceramah \\ Setelah dilakukan analisis} menggunakan uji Wilcoxon diperoleh hasil $p$ value sebesar $0,078>\alpha(0,05)$, maka H0 diterima dan Ha ditolak. Ini dapat disimpulkan bahwa tidak ada perbedaan pengetahuan CTPS sebelum maupun setelah dilakukan penyuluhan menggunakan metode ceramah. Penelitian ini sejalan dengan penelitian yang dilakukan oleh Azmidillah(7), tentang pengaruh pendidikan kesehatan menggunakan metode ceramah dan media leafleat terhadap perilaku cuci tangan diperoleh nilai probabilitas 0,157 setelah dianalisis dengan uji Wilcoxon.

1 Mahasiswa Jurusan Kesehatan Lingkungan Poltekkes Denpasar

2 Dosen Jurusan Kesehatan Lingkungan Poltekkes Denpasar 
Oleh karena nilai probabilitas $0,157>$ 0,05 maka Ho diterima ini berarti tidak terdapat perbedaan sebelum dan sesudah diberikan pendidikan kesehatan dengan media ceramah dan leaflet terhadap pengetahuan cuci tangan pada anak kelas 6 .

Tingkat pengetahuan seseorang dipengaruhi oleh beberapa faktor diantaranya umur, pendidikan, paparan media massa, sosial ekonomi serta pengalaman.

Pada saat pemberian penyuluhan siswa ada yang kurang memperhatikan sehingga informasi yang disampaikan tidak melekat dalam ingatan siswa. Selain itu pula dari metode yang digunakan yaitu metode ceramah memiliki kekurangan diantaranya membatasi daya ingat dan hanya satu indra yang digunakan yaitu indra pendengaran.

\section{Pengetahuan CTPS sebelum dan setelah diberi penyuluhan dengan metode ceramah kombinasi media video}

Setelah dilakukan analisis menggunakan uji Wilcoxon diperoleh $p$ value sebesar $0,320>\alpha(0,05)$, maka H0 diterima dan Ha ditolak. Ini dapat disimpulkan bahwa tidak ada perbedaan pengetahuan sebelum maupun setelah dilakukan penyuluhan menggunakan metode ceramah kombinasi media video.

Penelitian yang dilakukan oleh Wibawa(8), menggunakan metode demontrasi dengan pemutaran video tentang pemberantasan demam berdarah terhadap peningkatan pengetahuan dan sikap anak SD diperoleh nilai probabilitas $0,001<$ 0,05 , sehingga dapat dikatakan ada perbedaan yang bermakna antara pengetahuan responden pada waktu sebelum menerima perlakuan menggunakan metode pemutaran video dengan pengetahuan responden setelah menerima perlakuan menggunakan metode pemutaran video.

Awal penjelasan menggunakan metode ceramah siswa memperhatikan apa yang disampaikan oleh penyuluh tetapi setelah berjalannya penyuluhan, penyuluh tidak bisa memberikan penilaian terhadap reaksi siswa tersebut apakah mereka menangkap informasi yang disampaikan atau hanya sekedar mendengarkan saja. Hal tersebut merupakan salah satu kelemahan dari penggunaan metode ceramah. Saat pemutaran video siswa tertarik untuk menonton tetapi karena terfokus dengan gambar yang tampil di video menyebabkan siswa tidak begitu menyerap informasi yang disampaikan sehingga saat posstest hasilnya ada yang masih dengan hasil awal.

\section{Tindakan CTPS sebelum dan setelah diberi penyuluhan dengan metode ceramah}

Nilai $p$ value yang diperoleh sebesar $0,000<\alpha(0,05)$, maka $\mathrm{H} 0$ ditolak dan $\mathrm{Ha}$ diterima. Ini dapat disimpulkan bahwa ada perbedaan tindakan CTPS sebelum maupun setelah dilakukan penyuluhan menggunakan metode ceramah.

Penelitian sebelumnya yang dilakukan Azmidillah (7) tentang pengaruh pendidikan kesehatan menggunakan metode ceramah dan media leafleat terhadap perilaku cuci tangan diperoleh nilai probabilitas 0,000 setelah dianalisis dengan uji Wilcoxon. Oleh karena nilai probabilitas $0,000>0,05$ maka Ho ditolak ini berarti terdapat perbedaan sebelum dan sesudah diberikan pendidikan kesehatan dengan media ceramah dan leaflet terhadap perilaku (motorik) cuci tangan pada anak kelas 6. 


\section{Peningkatan tindakan siswa menggunakan metode ceramah dipengaruhi oleh pembicara yang sudah menguasai pokok pembahasan sehingga dimengerti oleh siswa. Disamping itu penggunaan metode ceramah baik untuk digunakan pada kelompok besar.}

\section{Tindakan CTPS sebelum dan setelah diberi penyuluhan dengan metode ceramah kombinasi media video}

Nilai $p$ value yang diperoleh sebesar $0,000<\alpha(0,05)$, maka H0 ditolak dan $\mathrm{Ha}$ diterima. Ini dapat disimpulkan bahwa ada perbedaan tindakan CTPS sebelum maupun setelah dilakukan penyuluhan menggunakan metode ceramah kombinasi media video.

Pada penelitian sebelumnya yang dilakukan oleh Wati, N., Yuniar, N., \& Paridah (9) terkait pengaruh intervensi penayangan video terhadap pengetahuan, sikap dan tindakan tentang cuci tangan pakai sabun pada siswa SD Negeri 10 Kabawo tahun 2016 hasil penelitian tersebut menunjukkan nilai p McNemar adalah $0,000<0.05$ sehingga secara statistik terdapat perbedaan tindakan tentang perilaku cuci tangan pakai sabun sebelum dan sesudah intervensi penayangan video pada siswa SD Negeri 10 Kabawo tahun 2016.

Peningkatan tindakan cuci tangan pakai sabun setelah dilakukan penyuluhan menggunakan metode ceramah dan media video disebabkan ada penyampaian informasi secara langsung dan gambar sehingga pesannya lebih melekat dalam ingatan siswa.

\section{Perbedaan penggunaan metode ceramah dengan metode ceramah kombinasi media video terhadap pengetahuan CTPS}

Setelah dilakukan analisis menggunakan uji Mann Whitney diperoleh $p$ value sebesar 0,283>0,05 ini dapat disimpulkan bahwa tidak ada perbedaan secara signifikan penggunaan metode ceramah dengan metode ceramah kombinasi media video terhadap pengetahuan CTPS siswa. video terhadap pengetahuan CTPS siswa.

Penelitian ini sejalan dengan penelitian yang dilakukan oleh Yustisa (10) mengenai efektivitas penggunaan media cetak dan media elektronika dalam promosi kesehatan menunjukkan hasil $p$ value sebesar 0,421 setelah diuji menggunakan uji Anova. Nilai $p$ value $>0,05$ ini berarti tidak ada perbedaan efektivitas penggunaan media cetak dan media elektronika terhadap peningkatan perubahan sikap PHBS siswa SD.

Menurut Kholid menunjukkan bahwa orang mengingat hanya $20 \%$ dari apa yang dilihat dan hanya $30 \%$ dari apa yang yang didengar, tetapi $70 \%$ dari apa yang mereka lihat maupun didengar. Dalam hal ini penggunaan metode ceramah memiliki kekurangan seperti komunikasi bersifat satu arah sehingga informasi yang didapat hanya dari fasilitator saja.

\section{Perbedaan penggunaan metode ceramah dengan metode ceramah kombinasi media video terhadap tindakan CTPS}

Setelah dilakukan analisis menggunakan uji Mann Whitney diperoleh $p$ value sebesar 0,361>0,05 ini dapat disimpulkan bahwa tidak ada perbedaan secara signifikan penggunaan metode ceramah dengan metode ceramah kombinasi media video terhadap tindakan CTPS siswa.

Penelitian ini sejalan dengan penelitian yang dilakukan oleh 
Pratiwi, dkk (12) mengenai pengaruh penyuluhan menggunakan metode permainan edukatif dan metode ceramah terhadap pengetahuan, sikap dan tindakan diperoleh hasil uji statistik dengan $\mathrm{p}$ value sebesar 0,084 . Dalam hal ini H0 diterima berarti tidak ada perbedaan tindakan responden tentang pencegahan penyakit diare antara kelompok eksperimen dengan kelompok kontrol sesudah penyuluhan di Kecamatan Poasia Kota Kendari Tahun 2015.

Siswa sangat antusias
mendengarkan informasi yang
disampaikan sehingga informasi yang
didapatkan diterapkan langsung oleh
siswa dengan melakukan praktek langsung di sekolah. Menurut Kholid (11) pengetahuan merupakan domain terpenting bagi terbentuknya tindakan seseorang. Perilaku yang didasari oleh pengetahuan akan lebih langgeng daripada perilaku yang tidak didasari oleh pengetahuan. Adanya sarana berupa wastafel, sabun dan lap tangan sebagai pendukung dalam melakukan kegiatan cuci tangan.

\section{Simpulan}

Berdasarkan hasil penelitian yang dilakukan diperoleh hasil sebagai berikut:

1. Tidak ada perbedaan pengetahuan CTPS sebelum maupun setelah dilakukan penyuluhan menggunakan metode ceramah ( $p$ $=0,078>\alpha(0,05))$.

2. Tidak ada perbedaan pengetahuan CTPS sebelum maupun setelah dilakukan penyuluhan menggunakan metode ceramah kombinasi media video ( $p=0,320$ $>\alpha(0,05))$.

3. Ada perbedaan tindakan CTPS sebelum maupun setelah dilakukan penyuluhan menggunakan metode ceramah. $(p=0,000<\alpha(0,05))$.
4. Ada perbedaan nilai tindakan CTPS sebelum maupun setelah dilakukan penyuluhan menggunakan metode ceramah kombinasi media video $(p=0,000$ $<\alpha(0,05))$.

5. Tidak ada perbedaan penggunaan metode ceramah dengan metode ceramah kombinasi media video terhadap pengetahuan CTPS siswa $(p=0,283>\alpha(0,05))$.

6. Tidak ada perbedaan penggunaan metode ceramah dengan metode ceramah kombinasi media video terhadap tindakan CTPS siswa $(p=$ $0,361>\alpha(0,05))$.

\section{Saran}

1. Bagi sekolah

Diharapkan dapat memberikan edukasi mengenai cuci tangan pakai sabun kepada siswa menggunakan metode ceramah maupun media video.

2. Bagi siswa

Siswa dapat membudayakan cuci tangan dan menerapkan cara cuci tangan yang benar.

3. Bagi Puskesmas

Sebaiknya menggunakan metode penyuluhan menggunakan metode ceramah dan media video untuk meningkatkan pencapaian tujuan promosi kesehatan pada anak sekolah tentang cuci tangan pakai sabun.

4. Bagi peneliti lain

a. Untuk menilai pengetahuan sebaiknya dilakukan wawancara dengan pertanyaan struktur kepada siswa sehingga dapat menyampaikan secara langsung apa yang diketahui.

b. Memilih sampel yang belum terpapar informasi agar tidak terjadi bias data.

c. Diharapkan dapat meneliti faktor yang mempengarhi 
pengetahuan seperti paparan media massa.

\section{Daftar Pustaka}

1. Kemenkes. Pedoman Umum Program Indonesia Sehat Dengan Pendekatan Keluarga. Kementerian Kesehatan RI.; 2016.

2. Mursida N. Pengaruh Media Booklet Terhadap Pengetahuan dan Sikap Tentang Perilaku Hidup Bersih dan Sehat (PHBS) pada Siswa di SMP Negeri I Palibelo. Ilmu Keperawatan. Sekolah Tinggi Kesehatan Jenderal Achmad Yani.; 2016.

3. Notoatmodjo S. Promosi Kesehatan \& Ilmu Perilaku. Jakarta: Rineka Cipta; 2007.

4. Lubis D. Pengaruh Penyuluhan Dengan Metode Ceramah dan Diskusi Terhadap Peningkatan Pengetahuan dan Sikap Anak Tentang PHBS di Sekolah Dasar Negeri 065014 Kelurahan Namogajah Kecamatan Medan Tuntungan Tahun 2013. 2013;

5. Anggraeni SE. Perbedaan Pendidikan Kesehatan Metode Demonstrasi Secara Langsung dengan Audio Visual Tentang Cuci Tangan Terhadap Praktik dan Perilaku Cuci Tangan. Ilmu Keperawatan. Fakultas Ilmu Kesehatan.; 2016.

6. Andrianus AA. Perbedaan Pengaruh Promosi Kesehatan Dengan Metode Video dan Modul Terhadap Praktik Cuci Tangan Pada Ibu Dengan Balita di Dusun Nglebeng Banguntapan Bantul Yogyakarta. Ilmu Keperawatan. Sekolah Tinggi Ilmu Kesehatan; 2016.
7. Azmidillah MR. Pendidikan Kesehatan Menggunakan Metode Ceramah dan Media Leaflet Terhadap Perilaku Cuci Tangan di SDN Sungai Bahadangan Kecamatan Banjang Kabupaten HSU. Program Studi S1 Keperawatan; 2017.

8. Wibawa C. Perbedaan Efektifitas Metode Demonstrasi Dengan Pemutaran VideoTentang Pemberantasan DBD Terhadap Peningkatan Pengetahuan dan Sikap Anak SD di Kecamatan Wedarijaksa Kabupaten Pati. J Promosi Kesehat Indones. 2007;2(2).

9. Wati, N., Yuniar, N. \& P. Pengaruh Intervensi Penayangan Video Terhadap Pengetahuan, Sikap dan Tindakan Tentang Cuci Tangan Pakai Sabun Pada Siswa SDN 10 Kabawo Tahun 2016. J Ilm Mhs Kesehat Masy. 2017;2(5):6.

10. Yustisa PF. Efektivitas Penggunaan Media Cetak dan Media Elektronika Dalam Promosi Kesehatan Terhadap Peningkatan Pengetahuan dan Perubahan Sikap Siswa SD. J Kesehat Lingkung. 2014;4(1):29.

11. Kholid A. Promosi Kesehatan : Dengan Pendekatan Teori Perilaku, Media dan Aplikasinya untuk Mahasiswa dan Praktisi Kesehatan. Jakarta: Rajawali Pers; 2014.

12. Pratiwi D. Pengaruh Penyuluhan Metode Permainan Edukatif dan Metode Ceramah Terhadap Pengetahuan, Sikap dan Tindakan Tentang Pencegahan Penyakit Diare Pada Murid SD di Kecamatan 
Jurnal Kesehatan Lingkungan Vol.8 No.1 Mei 2018: 13 - 22

Poasia Kota Kendari. Kendari:

Fakultas Kesehatan

Masyarakat. Universitas Halu

Oleo.; 2015.

1 Mahasiswa Jurusan Kesehatan Lingkungan Poltekkes Denpasar

2 Dosen Jurusan Kesehatan Lingkungan Poltekkes Denpasar 